\title{
Effect of Capital Structure, Company Size and Profitability on the Stock Price of Food and Beverage Companies Listed on the Indonesia Stock Exchange
}

\author{
Sitti Murniati \\ Moeslim Indonesian University, Indonesia \\ sittimurniati@ymail.com
}

\begin{abstract}
The purpose of this study was to analyze the effect of capital structure proxy for debt to asset ratio (DAR) and the debt to equity ratio (DER), company size and profitability are proxied by return on assets (ROA), return on equity (ROE) and net profit margin (NPM) to the stock price on the company's Food and Beverage listed on the Indonesia Stock Exchange. This study uses Associative approach. The population in this study is the Food and Beverage companies listed in Indonesia Stock Exchange year period 2011 to 2014. Sampling method used is purposive sampling and the amount of samples obtained is 11 companies with 44 observations. Hypotheses were tested using multiple regression analysis. Results of the study were 1) capital structure proxy for debt to asset ratio (DAR) significant negative effect on stock prices, this means that if a decline in the value of DAR, the stock price will rise, 2) capital structure proxy for debt to equity ratio (DER) significant positive effect on stock prices, it means that the higher the value of DER then be followed by a decrease in stock prices, 3) The company size significant positive effect on stock prices, this suggests that the relationship between the SIZE with stock prices in the same direction, if SIZE increases, the stock price will increase, 4) profitability is proxied by return on assets (ROA) significant positive effect on stock prices, this means that the assets of the company to make a profit can affect stock prices, 5) profitability proxied with a return on equity (ROE) significant negative effect, this means that if a decline in ROE it will be followed by a decrease in stock prices, and 6) Profitability which is proxied by net profit margin (NPM) significant negative effect on stock prices, this means that while the net profit increased, the total sales will rise this is due to the high costs incurred by the company so that NPM has no effect on stock prices.
\end{abstract}

Keywords: Debt to Asset Ratio, Debt to Equity Ratio, Company Size, Return on Assets, Return on Equity and Net Profit Margin

\section{Introduction}

The stock price of a company reflects the company's value in the investors, if a company's stock price high, then the value of the company in the investors is also good and vice versa, therefore the share price is important for the company (Purnomo, 2008). Theoretically variations in stock prices will be affected by the financial performance of a company, in addition affected by the law of supply and demand. Purnomo (2008), the stock price on the market provide an objective measure the value of an investment in the company. Therefore, the share price is investors' expectations. If the financial performance of the company increased indirectly will raise the price of shares on the Stock Exchange, as investors assume that the good performance of the company will increase the value of the company and can provide compensation to investors in the form of dividends. Conversely a decrease in the company's financial performance may cause the stock price on the Stock. Many variables can affect a company's stock price, both coming from the external environment or the advent of the internal environment of the company itself (Suad, 2008). In this study, researchers used the company's internal variables namely financial ratios and the size of the company that could affect the stock price. Financial ratios in the financial statements can also help investors in making the decision to sell or buy shares (Suad, 2008). In addition, consideration is used investors in shares is the size of the company, as variables that can predict changes in the company's stock price.

Capital structure is the ratio between debt and equity capital used by enterprises (Suad, 2008). In this study, projected capital structure with a debt to asset ratio (DAR) and the debt to equity ratio (DER). DAR is used to measure the total amount financed by the financing needs of the total debt (Retno, 2010). DER is a ratio showing the ratio between loans granted by the creditors with the amount of equity capital provided by the owners of the company (Suad, 2008). Variable company size is very dependent on the size of the company. 
Large companies more easily obtain loans because the value of the assets pledged as collateral larger and bank confidence level is also higher. Assets that may be of tangible fixed assets and other assets such as accounts receivable and inventory (Wiliandri, 2011). A profitability ratio is the ratio for assessing the ability of the enterprise for profit in a given period (Kasmir, 2011). In this study, projected profitability by Return on Assets (ROA), Return on Equity (ROE) and net profit margin (NPM). ROA measures the company's ability to generate net income under a certain level of assets (Hanafi, 2013). ROE measures the company's ability to generate net income under certain capital (Hanafi, 2013). NPM is a ratio that measures the rupiah profit generated by each of the rupiah sales, (Prastowo, 2005). In theory and the results of previous studies indicates that the financial ratios of debt to asset ratio (DAR), debt to equity ratio (DER), company size, return on assets (ROA), return on equity (ROE) and net profit margin (NPM) linked to stock price. On this basis, the researchers selected financial ratios (DAR, DER, ROA, ROE, and NPM) and the size of the company as a variable that can predict changes in stock prices Food and Beverage companies listed in the Indonesia Stock Exchange. Many theories which states that the ratio of good financial condition and large size companies that will bring a positive influence on the stock price, so what the results of the research will reinforce and strengthen the existing theories. Based on the description that has been said, the main problem in this study is whether the capital structure proxy for debt to asset ratio (DAR) and the debt to equity ratio (DER), company size and profitability are proxied by return on assets (ROA), return on equity (ROE) and net profit margin (NPM) affect the price of shares in the company Food and Beverage listed on the Indonesia Stock Exchange.

\section{Literature Review}

Stock price: Tjiptono and Hendy (2011) shares may be defined as a sign of ownership or possession of a person or entity in a corporation or limited liability company. Sunariyah (2006) is a certificate of ownership of the company that pays the stock. Sartono (2007) is proof of delivery of the fund company's capital. The third opinion can be concluded that the shares are securities as evidence of ownership of one's capital position in a company or entity. The stock price is the price that is happening in the stock market at the appropriate time determined by market participants and is determined by demand and supply of the relevant shares in the capital market. Meanwhile, according to Suad (2008), the stock price is the current price of the earnings to be received by investors in the future. A stock price used in transactions in the capital market is a price formed on the market mechanism of demand and supplies that market.

Capital Structure: Horne and Wachowicz (2007) capital structure is the proportion of the company's long term permanent financing represented by debt, equity preferred shares and common stock. In this study, the capital structure is proxied by debt to asset ratio (DAR) and the debt to equity ratio (DER). Sibarani (2009), DAR shows the proportion of debt held and all property owned, in order to secure the portion of the debt must be smaller to assets. Mulyadi (2007), debt to equity ratio illustrates the ratio between total debt and total equity of the company used as a source of business funding.

Company size: Size is a scale which can be classified on the size of firms by total assets, net sales, and the company's market capitalization. Widjaja (2009), the size of the company is a measure that indicates the size of a company, such as total sales, the average level of sales, and total assets. Company size using book value of total assets or total assets as a proxy for size. This ratio is also used in Paramu research, considering the great value of the company's assets in the process of calculating the total asset value is calculated in millions of rupiah and transformed into natural logarithm (Ln).

Profitability: Profitability is the company's ability to generate profits with the resources of the company. In this study, profitability is proxied by Return on Assets (ROA), Return on Assets (ROA) and Net Profit Margin (NPM). Return on Assets (ROA) is a ratio that measures the company's ability to generate net income under a certain level of assets (Hanafi, 2013). Return on Equity (ROE) measures the ability of the company generate a net profit based on certain capital (Hanafi, 2013). Net Profit Margin (NPM) is a ratio that measures the rupiah profit generated by each of the rupiah sales (Prastowo, 2005). Optimizing the value of the company which is the company's goals can be achieved through the implementation of financial functions, where by each financial decisions taken will affect other financial decisions and have an impact on stock prices. Based on the description above, it can be described as a conceptual framework on label the following: 
Figure 1: Conceptual Framework

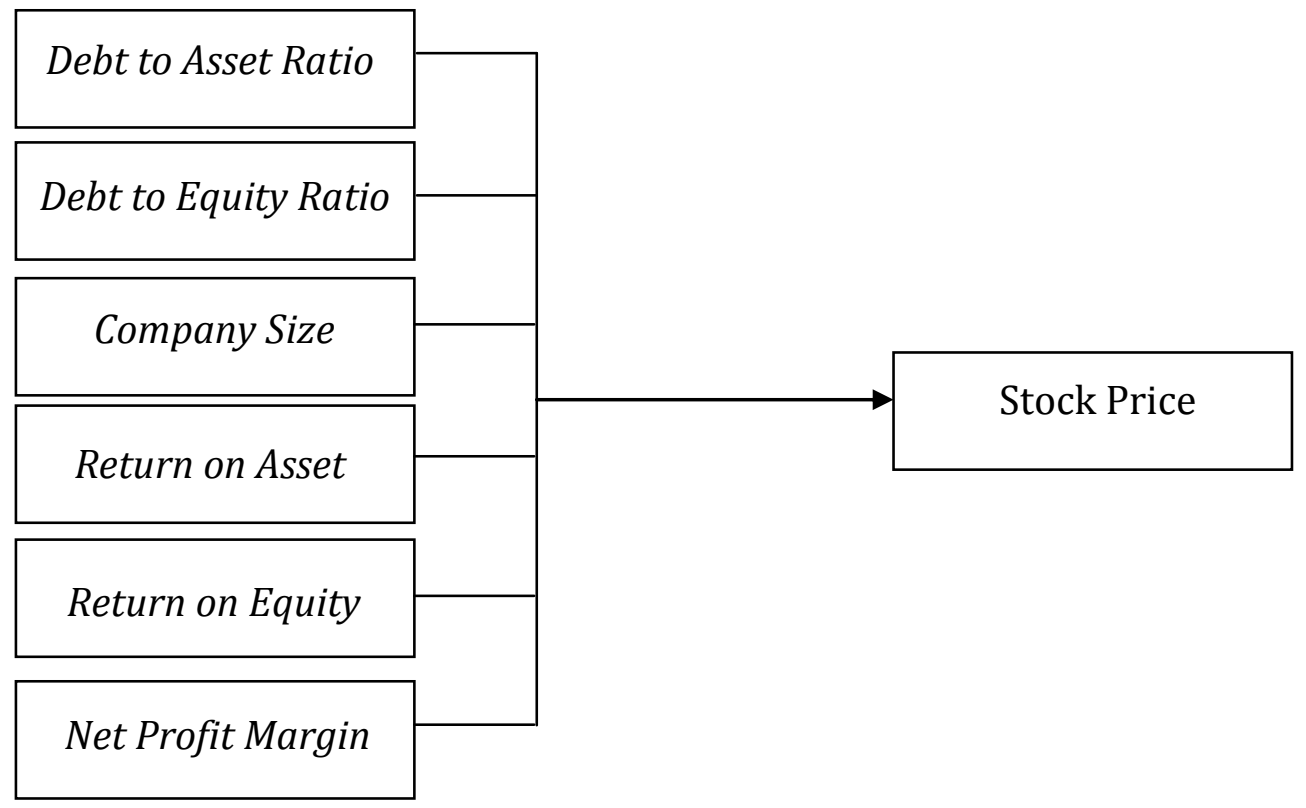

\section{Methodology}

This study uses Associative approach. This study is included in a causal relationship. The causal relationship is a relationship that is both cause and effect is as follows: independent variables (variables that affect) and the dependent variable (the variable that is affected) (Sugiyono, 2013). The population in this study is the Food and Beverage companies listed in Indonesia Stock Exchange year period 2011 to 2014 amounted to 15 companies. The method used is purposive sampling is a type of non-random sample selection in which information is obtained by using judgment or certain criteria. Judging from the data collection period, the data including the pooling of data which is a combination of time series data (data collected from time to time to see the development of an event). Based on pre-defined criteria, the numbers of samples obtained are 11 companies with 44 observations. Multiple regression tests aims to predict the magnitude of association with the use of variable data free of known magnitude. To test this hypothesis using multiple regression analysis. Multiple regression analysis was used to predict major dependent variables using data from the independent variable. Sugiyono (2013) to test the hypothesis in this study used the following models:

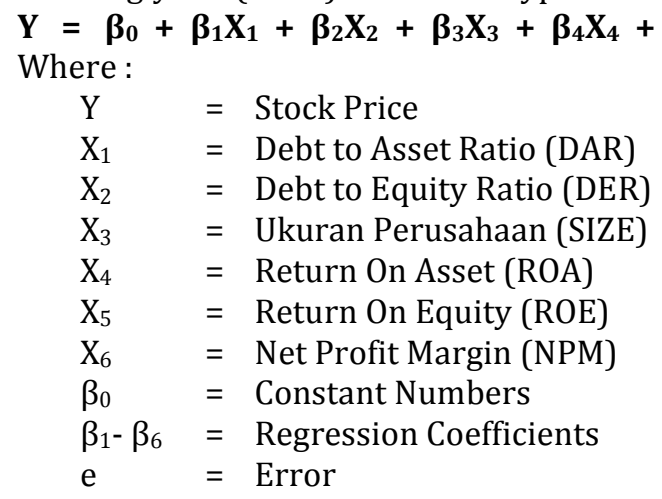

\section{Results and Discussion}

Model analysis used is multiple linear analyses. This analysis is used to determine the direction and magnitude of influence between free variable that debt to asset ratio (X1), debt to equity ratio (X2), size (X3), return on assets (X4), return on equity (X5) and net profit margin (X6) to the stock price on the company's 
Food and Beverage listed on the Indonesia Stock Exchange for 4 years, namely the period 2011 to 2014. Based on the results of data processing of the obtained multiple regression equation as follows:

Table 1: Results of Multiple Regression Analysis

\begin{tabular}{llll}
\hline Variable & $\begin{array}{l}\text { Unstandardized } \\
\text { Coefficients }\end{array}$ & t-test & $\begin{array}{l}\text { p-value } \\
\text { (Significant) }\end{array}$ \\
\hline (Constant) & -5.419 & -4.156 & 0.000 \\
DAR & -33.606 & -3.334 & 0.002 \\
DER & 27.346 & 2.727 & 0.010 \\
SIZE & 0.525 & 4.882 & 0.000 \\
ROA & 23.323 & 2.241 & 0.031 \\
ROE & -20.763 & -2.013 & 0.051 \\
NPM & -0.892 & -1.832 & 0.075 \\
& & Description: & \\
$\mathrm{R}^{2}$ & & Significant to & \\
R & 0.806 & *p<0,05 & \\
F-test & 0.898 & & \\
Sig.F & 25.563 & & \\
\hline Source & 0,000 & & \\
\hline
\end{tabular}

Source: Data processed

From the table it can be seen that all the independent variables, namely the debt to asset ratio (X1), debt to equity ratio (X2), size (X3), return on assets (X4), return on equity (X5) and net profit margin (X6) effect on the dependent variable is the stock price $(\mathrm{Y})$. By looking at the table the results of multiple linear regressions, we can conclude that:

- Simultaneously variable debt to asset ratio (DAR), debt to equity ratio (DER), size of the company, return on assets (ROA), return on equity (ROE) and net profit margin (NPM) and the positive effect significantly influence stock prices. It can be seen from the calculated $\mathrm{F}$ value that indicates a value of $25,563$ (significance $\mathrm{F}=0.000)$. So Sig F $<5 \%(0,000<0,05)$.

- Partially variable debt to asset ratio (DAR) significant negative effect on stock prices. It can be seen from the $t$-value for the DAR to the stock price is -3.334 with a significant level of 0,002 . So Sig. $t<5$ $\%(0,002<0,05)$.

- Partially variable debt to equity ratio (DER) significant positive effect on stock prices. It can be seen from the $t$-value for the DER to the stock price is 2.727 with a significant level of 0,010 . So Sig. $t<5 \%$ $(0,010<0,05)$.

- Partially variable company size significant positive effect on stock prices. It can be seen from the $t$ value for the SIZE of the stock price is 4882 with a significant level of 0,000 . So Sig. $t<5 \%(0,000<$ $0,05)$

- Partially variable return on assets (ROA) significant positive effect on stock prices. It can be seen from the $t$ value for ROA on stock prices is a significant level of 2,241 to 0,031 . So Sig. $t<5 \%(0,031<$ $0,05)$.

- Partially variable return on equity (ROE) significant negative effect on stock prices. It can be seen from the $t$ value for ROE on stock prices is $-2,013$ with a significant level of 0,051 . So Sig. $t>5 \%$ $(0,051>0,05)$.

- Partially variable net profit margin (NPM) significant negative effect on stock prices. It can be seen from the $t$ value for NPM on stock prices is $-1,832$ with a significant level of 0,075 . So Sig. $t>5 \%$ $(0,075>0,05)$.

The correlation coefficient (R) is used to determine the relationship between the independent variable and the dependent variable. Results obtained by analysis of the correlation coefficient (R) shows the relationship between the variable $\mathrm{X}$ with variable $\mathrm{Y}$ of 0,898 which means that there is a positive relationship and the direction between variables $\mathrm{X}$ with variables $\mathrm{Y}$ at $89,8 \%$. The value of coefficient of determination is used to determine the effect of independent variables on the dependent variable. R2 value lies between 0 and $1(0 \leq$ $\mathrm{R} 2 \leq 1$ ). Results obtained by analysis of the coefficient of determination (R2) of 0.806 means, the effect of variable $\mathrm{X}$ (debt to asset ratio, debt to equity ratio, size, return on assets, return on equity and net profit 
margin) to variable $\mathrm{Y}$ (the stock price) of $80.6 \%$ and the effect of other variables of $19.4 \%$ which is not included in the model. This influence is in excellent because the value obtained above $60 \%$. By looking at the results table multiple linear regression can be obtained regression equation is:

$Y=-5,419-33,606 X_{1}+27,346 X_{2}+0,525 X_{3}+23,323 X_{4}-20,763 X_{5}-0,892 X_{6}$

The regression equation can be interpreted as follows:

- $\mathrm{b}_{0}=-5,419$ is a constant number which indicates that the stock price $(\mathrm{Y})$ is not determined by the DAR variable $\left(\mathrm{X}_{1}\right)$, DER $\left(\mathrm{X}_{2}\right)$, SIZE $\left(\mathrm{X}_{3}\right)$, ROA $\left(\mathrm{X}_{4}\right)$, ROE $\left(\mathrm{X}_{5}\right)$ and $\mathrm{NPM}\left(\mathrm{X}_{6}\right)$

- $\mathrm{b}_{1}=-33,606$ indicates that if the DAR (X1) increased by $1 \%$, then the stock price $(\mathrm{Y})$ will decrease by $336,06 \%$.

- $\mathrm{b}_{2}=27,346$ indicates that if the DER (X2) increased by $1 \%$, then the stock price (Y) will increase by $273,46 \%$.

- $\mathrm{b}_{3}=0,525$ shows that when the SIZE (X3) increased by $1 \%$, then the stock price (Y) will increase by $52,5 \%$.

- $\mathrm{b}_{4}=23,323$ showed that when ROA (X4) increased by $1 \%$, then the stock price (Y) will increase by $233,23 \%$.

- $b_{5}=-20,763$ indicates that if ROE (X5) increased by $1 \%$, then the stock price (Y) decreased by $207,63 \%$.

- $\mathrm{b}_{6}=-0,892$ showed that when NPM (X6) increased by $1 \%$, then the stock price $(\mathrm{Y})$ will decrease by $89,2 \%$.

From these calculations can also be seen that the most dominant variable influence on stock prices at the Food and Beverage listed on the Indonesia Stock Exchange is a variable return on assets (X4), because the value of Standardized Coefficients Beta ROA is greater than the variable debt to asset ratio (X1), debt to equity ratio (X2), size (X3), return on equity (X5) and net profit margin (X6). To facilitate discussion of the results, then the next will be described the test results for each hypothesis of the study, as follows:

Effect of capital structure proxy for debt to asset ratio (DAR) on stock prices: Debt to asset ratio (DAR) is the ratio used to measure the total amount financed by the financing needs of the total debt. This means that the higher the ratio the greater the amount of capital loans used for investments in assets in order to generate profits for the company. While DAR low value indicates that the fund companies slightly financed by debt, it could affect the stock price increases. Based on the results of multiple linear regressions, proxy variable capital structure with a debt to asset ratio (DAR) to orientate a significant negative impact. This means that the variable debt to asset ratio (DAR) significant negative effect on the stock price on the company's Food and Beverage listed on the Indonesia Stock Exchange. This means that if a decline in the value of DAR, the stock price will rise. DAR significant negative effect on stock prices occur due to debt to asset ratio, which will increase the stock price as investors reacted negatively. The statement is also supported by the Modigliani-Miller theory which states that the higher the debt to asset ratio, the share price will fall. As noted by Syamsuddin (2009) that the higher the debt to asset ratio, the greater the amount of loan capital used in generating profits for the company.

Effect of capital structure proxy for debt to equity ratio (DER) on stock prices: Debt to equity ratio (DER) describes the ratio between total debt and total equity of the company used as a source of business funding. The greater the DER indicates capital structure more businesses take advantage of debt relative to equity and reflects the company's relatively high risk. Based on the results of multiple linear regressions, proxy variable capital structure with a debt to equity ratio (DER), which indicates the direction a significant positive effect. This means that the variable debt to equity ratio (DER) significant positive effect on the stock price on the company's Food and Beverage listed on the Indonesia Stock Exchange. This means that the higher the value of the debt to equity ratio (DER) will then be followed by a decline in stock prices. These results support the results of Ircham (2014) which states that DER significant positive effect on stock prices show that investors pay attention to how much capital is financed by them to the company to generate a net profit for them. The greater the DER indicates capital structure more businesses utilizing funds provided by the creditor to make a profit. Pecking order theory, the magnitude of the leverage ratio makes companies have to bear the high cost of interest that must be met, this will impact on the company's stock price. 
Effect of size of the company to the stock price: Company size is a measure that indicates the size of a company, such as total sales, the average level of sales, and total assets. In general, large companies have total assets greater so as to attract investors to invest in the company and the stock eventually able to survive at a high price. Based on the results of multiple linear regressions, the variable size of the company that indicates the direction of a significant positive effect. This means that the variable size of the company's significant positive effect on the stock price on the company's Food and Beverage listed on the Indonesia Stock Exchange. This shows that the relationship between firm size and direction of the share price, in the sense that if the size of the company increases, the stock price will increase. These results indicate that the size of the company's size will affect the size of the stock price. This study is consistent with the results Widjaja (2009) which states that the firm size (the size of the company) as measured by total assets positive and significant impact on the prospects of the company's shares. Opinion was confirmed by Wiliandri (2011) that the greater the size of a company (size) which can be seen from the total assets of a company, the company's stock price higher, whereas if the size of the smaller companies, the share price will be even lower. It means that investors in the capital market will be more attracted to companies that have total assets of large because large companies more easily obtain loans due to the value of assets pledged as collateral is greater and the level of trust banks are also higher so that the market price of the company's shares in the Indonesian Stock Exchange will increase.

Effect of profitability proxied by return on assets (ROA) on stock prices: Return on assets is a financial ratio that shows the company's ability to generate profits from assets that are used. The higher the ROA of a company, the higher the value of the company's assets and lead to higher stock prices as much in demand by investors. this can be due if the company can make a profit or a nice profit each period, investors do not need to worry about the company to post a loss or even bankruptcy. Based on the results of multiple linear regressions, the variable profitability proxied by return on assets (ROA) which indicates the direction a significant positive effect. This means that the variable return on assets (ROA) significant positive effect on the stock price on the company's Food and Beverage listed on the Indonesia Stock Exchange. This means that the assets of the company may affect the stock price. These results support the results of Nardi (2014) which shows that ROA has a positive and significant impact on stock prices of Food and Beverage companies listed in the Indonesia Stock Exchange. This shows that management can use the total assets of the company as well (current assets and fixed assets) and will ultimately improve the company's stock price so that investors are interested to invest in the Food and Beverage.

Effect of profitability proxied by return on equity (ROE) to share price: Return on equity (ROE) illustrates the power level of income that will be earned by the shareholders on the investments made and this ratio can also be used to compare two or more companies in the industry. High ROE indicates that the company has the opportunity to provide income for shareholders. Conditions good companies will generate profits so high that the possibility of the company makes a profit is also getting better. Based on the results of multiple linear regressions, the variable profitability proxied by return on equity (ROE), which indicates the direction a negative influence is not significant. This means that the variable return on equity (ROE) significant negative effect on stock prices at the Food and Beverage companies listed in the Indonesia Stock Exchange. This means that if there is a decrease ROE it will be followed by a decline in stock prices. This means that proxy for profitability ROE tends to lower investor interest in the company's stock if the value of the low ROE. This shows the inability of the company Food and Beverage is not maximized in using their own capital to generate profit, if the growth rate value is lower than the specified value of the stock price will also be lower. These results support the results of Ircham (2014) which states that ROE significant negative effect on stock prices. Low ROE figures give an indication to shareholders that the lower rate of return on investment. Conditions were not good company will generate profits so low that the possibility of generating stock returns was low anyway (Tandelilin, 2010).

Effect of profitability proxied by net profit margin (NPM) on stock prices: Net profit margin is the ratio between the net profits after tax to sales measures the net profit generated from each sale of rupiah. The greater this ratio, it is considered the better the company's ability to obtain high profits. Rinati (2008), the greater the NPM, the performance of the company will be more productive, so it will increase the confidence of investors to invest in the company, with increasing investor will affect the company's stock price will increase. Based on the results of multiple linear regressions, proxy variable profitability with net profit 
margin (NPM), which indicates the direction a negative influence is not significant. This means that the variable net profit margin (NPM) significant negative effect on stock prices at the Food and Beverage companies listed in the Indonesia Stock Exchange. This means that while net income rose, the total sales will rise this is due to the high costs incurred by the company so that NPM has no effect on stock prices. This means that the management has failed in operational terms (sales) and this will lead to diminished confidence of investors to invest in companies of Food and Beverage. The results support the research Rinati (2008), that the NPM has no effect on stock prices. This means that the relationship between net income and the tax residual net sales shows the inability of the management to drive the company so that the management did not manage to retain a certain margin as reasonable compensation for the owner who has provided capital to a risk.

\section{Conclusion and Recommendations}

Based on the results of research and discussion that has been raised, the conclusions in this study is a capital structure that is proxied by debt to asset ratio (DAR) and the debt to equity ratio (DER), firm size (SIZE) and profitability are proxied by return on assets (ROA), return on equity (ROE) and net profit margin (NPM) affect the price of shares in the company Food and Beverage listed on the Indonesia Stock Exchange. Recommendations of this study is the variable that is not proven effect on the study should in future research to use a proxy other than the variable, which is expected to reflect the variables used.

\section{Reference}

Hanafi, M. (2013). Financial Management. Publisher: BPFE, Yogyakarta.

Horne \& Wachowicz. (2007). Principles of Financial Management. Publisher: Salemba Four. Jakarta.

Ircham, M. (2014). Effect of Capital Structure and Profitability on the Stock Market in BEI. Brawijaya University.

Kasmir. (2011). Analysis of Financial Statements. First Edition Prints Fourth, Eagle Press, Jakarta.

Mulyadi. (2007). Financial Management: Quantitative Approach and Kuaitatif. Publisher: Bayumedia. Poor.

Nardi. (2014). Effect of Current Ratio, Debt To Equity Ratio, Net Profit Margin, and Return On Investment Share Price On Food and Beverage Company Listed on the Stock Exchange. Maritime Raja Ali Haji, Tanjungpinang.

Prastowo, D. (2005). Analysis of Financial Statements. Second edition of the College of Management Sciences, YKPN, Yogyakarta

Purnomo, H. (2008). Effect of Financial Performance Share Price Corporate Banking In BEI, Semarang University.

Retno, D. (2010). Analysis of Financial Statements. Poor.

Rinati, I. (2008). The influence of NPM, ROA, and ROE for the Company's Stock Price to Listed LQ45 index. Gunadarma University.

Sartono, A. (2007). Financial Management Theory and Applications. 4th Edition Publisher: BPFE. Yogyakarta.

Sibarani, T. \& Princess, M. (2009). Influence Analysis DTAR and DER against EPS in Sector Company Property and the Manufacturing Sector Go Public in BEI. North Sumatera University.

Suad, H. (2008). Basics Portfolio Theory and Analysis Securities. Fourth Edition. Publisher: STIM YKPN. Yogyakarta.

Sugiyono. (2013). Business Research Methods. Fifteenth mold, Publisher: Alfabeta, Bandung.

Sunariyah. (2006). Introduction to Knowledge Capital Markets. Publisher: UPP AMP YKPN. Yogyakarta.

Syamsuddin, L. (2009). Corporate Financial Management: Concepts Applications in Planning, Monitoring and Decision Making. Publisher: PT RajaGrafindo Persada. Jakarta.

Tandelilin, E. (2010). Portfolio and Investment (Theory and Application), First Edition. Publisher: Canisius. Yogyakarta.

Tjiptono, D. \& Fakhrudin, H. M. (2011). The Capital Market in Indonesia. Publisher: Salemba Four.

Widjaja, I. (2009). Effect of Firm Size and Structure of Prospect Capital Stock Company. Journal of Organization and Management, 2(1), 21-30.

Wiliandri, R. (2011). Effect of blockholder Ownership and Firm Size of Corporate Debt Policy. Journal of Business Economics, 16(2), 95-102. 